\title{
IMPLEMENTASI THE HIDDEN CURRICULUM DALAM MENUMBUHKAN KARAKTER ISLAMI
}

\author{
Anjani Wira Murti \\ Sekolah Menengah Pertama Negeri 6 Surakarta \\ E-Mail: anjanimurti13@gmail.com
}

\begin{abstract}
Abtract: This study aims to describe the implications of co-curriculer improving the student's Islamic character and to know the supporting and inhibiting factors of implementing co-curiculer at the eighth grade of MTs Negeri I and II Wonogiri. This type of research is qualitative research. The subjects of this study were headmasters, Islamic teachers, and students at the eighth grade of MTs Negeri I and II Wonogiri. The objects of this study are Islamic habituation activities that exist in MTs Negeri I and II Wonogiri. The techniques of collecting the data through observation, interviews, and documentation. The data analysis techniques used descriptive qualitative. The results of the research show that (1) the implications of co-curriculer in improving the student's Islamic character at the eighth grade of MTs Negeri I and II Wonogiri are: (a) the implication to the students are: through habituation which is conducted in the schools, the student will be discipline in doing his obligations such as prayer. The students also become more polite and noble. This shows that the student's attitude change be better is because of the application of co-curriculer in the school, (b) implications for schools: through co-curriculer, schools can achieve vision and mission. Co-curriculer also gives great benefits for schools, because with the existence of Islamic activities can make the name of the school more superior in the community. Besides that, by implementation of Islamic habituation activities and the existence of special program classes can also affect the school is superior.(2) The supporting factors of co-curriculer at the eighth grade of MTs Negeri I and II Wonogiri are: (a) The existence of Islamic teachers, (b) The closeness between teachers and students through communication, (c) the holding of ESQ activities, (d) Facilities and infrastructure are complete, and (e) Supportive school environments.(3) The inhibiting factors of implementing co-curriculer in improving the student's Islamic character are: (a) Awareness of students who are still less obedient in worship, (b) less of attention from parents, (c) Many of the students left by their parents go abroad, and (d) student living environment that is still less obedient in worship.
\end{abstract}

Keywords: co-curriculer; islamic; character

\begin{abstract}
Abstrak: Penelitian ini bertujuan untuk mendiskripsikan implikasi ko-kulikulerdalam menumbuhkan karakter Islami siswa dan untuk mengetahui faktor pendukung dan penghambat pelaksanaan ko-kurikuler dalam menumbuhkan karakter Islami siswa pada kelas VIII di MTs Negeri I dan II Wonogiri. Jenis penelitian ini adalah penelitian kualitatif.Subjek dalam penelitian ini adalah kepala sekolah, guru pembina keagamaan, dan siswa kelas VIII di MTS Negeri I dan II Wonogiri.Objek dalam penelitian ini adalah kegiatan pembiasaan keagamaan yang ada di MTs Negeri I dan II Wonogiri. Teknik pengumpulan data melalui observasi, wawancara, dan dokumentasi.Teknik analisis data menggunakan deskriptif kualitatif. Hasil penelitian menunjukkan bahwa (1) implikasi dari ko-kulikulerdalam menumbuhkan karakter Islami siswa pada kelas VIII di MTs Negeri I dan II Wonogiri yaitu: (a) implikasi terhadap siswa: melalui pembiasaan yang dilaksanakan di sekolah, siswa akan menjadi disiplin dalam melaksanakan kewajibannya seperti shalat. Siswa juga menjadi lebih santun dan berakhlak mulia. Hal tersebut menunjukkan bahwa perubahan sikap siswa menjadi lebih baik karena diterapkannya ko-kulikulerdi sekolah, (b) implikasi terhadap sekolah: melalui ko-kurikuler, sekolah dapat mencapai visi dan misi. Ko-kulikulerjuga memberikan manfaat besar bagi sekolah, karena dengan adanya kegiatan keagamaan dapat menjadikan nama sekolah semakin unggul di masyarakat. Selain itu dengan diterapkannya kegiatan pembiasaan keagamaan dan adanya kelas program khusus juga dapat mempengaruhi sekolah lebih unggul.(2) faktor pendukung ko-kulikulerdalam menumbuhkan karakter Islami siswa pada kelas VIII di MTS Negeri I dan II Wonogiri yaitu: (a) Adanya guru pembina keagamaan, (b) Kedekatan antara guru dengan siswa melalui komunikasi, (c) diadakannya kegiatan ESQ, (d) Sarana dan prasarana yang lengkap, dan (e) Lingkungan sekolah yang mendukung.(3) Faktor penghambat pelaksanakan ko-kulikulerdalam menumbuhkan karakter Islami siswa yaitu: (a) Kesadaran siswa yang masih kurang taat dalam beribadah, (b) kurangnya perhatian dari orang tua, (c) Banyak siswa yang ditinggalkan orang tuannya pergi merantau, dan (d) lingkungan tempat tinggal siswa yang masih kurang taat dalam beribadah.
\end{abstract}

Kata Kunci: ko-kurikuler; karakter; islami. 


\section{PENDAHULUAN}

Pendidikan pada dasarnya merupakan upaya untuk menumbuh kembangkan potensi dan kepribadian peserta didik sehingga menjadi pribadi yang cerdas, berakhlak mulia, dan memiliki kemampuan dan keterampilan yang berguna bagi dirinya sendiri, masyarakat, dan negara.Pendidikan juga disebut sebagai proses memanusiakan manusia, menjadikan manusia yang cerdas secara intelektual dan juga bermoral yang baik.

Pendidikan itu sendiri sangat penting dalam aspek kehidupan sehari-hari. Allah SWT akan meninggikan derajat bagi orang-orang yang beriman dan berilmu, sebagaimana yang dijelaskan dalam firman Allah Q.S Al-Mujādalah ayat 11:

"Allah akan meninggikan orang-orang yang beriman di antaramu dan orang-orang yang diberi ilmu pengetahuan beberapa derajat"

(Q.S Al-Mujādilahayat 11).1

Pendidikan yang baik bukan hanya sekedar melahirkan orang-orang yang cerdas otak dan keahliannya saja, namun juga menjadikan orangorang yang mulia kepribadian dan juga tindakannya untuk menjadi manusia yang berinsan kamil.

Salah satu aspek penting dalam proses pendidikan adalah membangun sebuah karakter peserta didik. Karakter merupakan standar atau norma dalam sistem nilai yang terimplikasi dalam berbagai bentuk kualitas diri. Oleh karena itu, pendidikan yang mengembangkan karakter adalah bentuk pendidikan yang bisa membantu mengembangkan etika, moral, dan tanggung jawab.

Seperti yang terdapat pada Undang-undang No. 20 tahun 2003 tentang Sistem Pendidikan Nasional (Sisdiknas) telah menegaskan bahwa:

Pendidikan Nasional berfungsi mengembangkan kemampuan dan membentuk watak serta peradaban bangsa yang bermartabat dalam rangka mencerdaskan kehidupan bangsa, bertujuan untuk berkembangnya potensi peserta didik agar menjadi manusia yang beriman dan bertakwa kepada Tuhan Yang Maha Esa, berakhlak mulia, sehat, berilmu, cakap, kreatif, mandiri, dan menjadi warga negara yang demokratis serta bertanggung jawab. 2

Pendidikan karakter bukanlah masalah baru bagi masyarakat, bahkan sudah ada sejak awal kemerdekaan, masa order lama, order baru, dan sekarang order reformasi. Pendidikan karakter juga sebenarnya sudah lahir bersamaan dengan lahirnya pendidikan.Karena pendidikan itu sendiri untuk mengembangkan karakter menjadi lebih baik.3

Pendidikan karakter memiliki esensi dan makna yang sama dengan pendidikan akhlak dan pendidikan moral. Tujuannya yaitu membentuk pribadi anak 1 Departemen Agama RI, al-Qur'an dan Terjemahan, (Bandung: PT. Sigma Examedia Arkanleema, 2007), hlm. 544. 2 Undang-Undang RI No 20 Tahun 2003 tentang Sistem Pendidikan Nasional, (Jakarta: Departemen Pendiidkan Nasional RI, 2003), hlm. 6.

3 Hamdani Hamid dan Beni Ahmad Saebeni, Pendidikan Karakter Perspektif Islam, (Bandung: Pustaka Setia, 2013), hlm. 30. menjadi manusia setuhnya yang lebih baik, warga masyarakat, dan warga negara yang baik.

Menghadapi berbagai persoalan yang global pendidikan tidak hanya cukup menanamkan kemampuan kecerdasan dan iptek saja, tetapi haruslah memberikan bekal kepribadian, moral yang kuat. Contohnya saja di Indonesia masih terdapat masalah tentang korupsi dan berbagai penyimpangan perilaku seperti, bergaya hidup hedonis dan ajimumpung, manusia yang gampang tergoda oleh harta dan kekuasaan, ingin hidup mewah dan sukses yang ditempuh dengan cara serba instan dengan menggunakan cara-cara yang tidak halal.

Prilaku yang menyimpang lainnya yang terjadi dikalangan pelajar misalnya sering terjadinya tawuran, pergaulan bebas, suka minum-minuman keras, terlibat mengkomsumsi narkoba, maraknya geng motor yang sering meresahkan masyarakat bahkan bertindak kriminal seperti pemalakan dan pembunuhan. Hal tersebut sangatlah mencoreng nama baik pelajar dan juga lembaga pendidikan. Maka akar dari permasalahan tersebut yaitu terletak pada karakter manusianya.

Apapun tantangan atau godaan yang menghadang jika karakter yang ada pada dirinya kuat, maka tidak akan menjatuhkan diri pada prilaku-prilaku yang menyimpang dan melampaui batas. 4

Banyak anggapan menyadari bahwa pendidikan karakter bukan pekerjaan yang instan yang mudah dilakukan. Karena hal ini menyangkut bukan hanya penyelenggaraan proses pendidikan yang tidak sederhana tetapi juga karena berkaitan dengan pembentukan budi pekerti atau akhlak secara utuh agar menjadikan manusia seutuhnya yang bersifat kompleks.

Pendidikan karakter perlu diupayakan dan diimplikasikan pada jalur pendidikan formal dan informal.Lembaga pendidikan khususnya di sekolah dipandang sebagai tempat yang strategis untuk membentuk karakter.Hal ini dimaksudkan agar peserta didik dalam segala ucapan, sikap, dan prilakunya mencerminkan karakter yang baik dan kuat.5Sebab, pendidikan karakter perlu dikembangkan melalui tahap pengetahuan (knowing), pelaksanaan (acting), dan kebiasaan (habit).

Untuk mencapai sebuah pembelajaran agar berjalan dengan baik perlu adanya kurikulum. Kurikulum sendiri menjadi pedoman bagi para guru untuk menunjang belajar peserta didik kearah yang lebih baik.Kurikulum sendiri didefinisikan sebagai suatu bahan ajar yang tertulis yang berisikan uraian tentang program pendidikan sekolah atau madrasah yang harus dilaksanakan dari tahun ke tahun.6

Ada sejumlah ahli teori kurikulum yang berpendapat bahwa kurikulum bukan hanya meliputi semua kegiatan yang direncanakan melainkan juga peristiwa-pristiwa yang terjadi dibawah pengawasan sekolah, jadi selain kegiatan kulikuler yang formal juga terdapat kegiatan yang tak formal yang sering 4 Haedar Nashir, Pendidikan Karakter Berbasis Agama dan Budaya, (Yogyakarta: Multi Presindo, 2013), hlm. 5.

5 M. Furqon Hidayatullah, Pendidikan Karakter: Membangun Peradaban Bangsa, (Surakarta: Yuma Pressindo, 2010), hlm. 3 6 Soleh Hidayat, Pengembangan Kurikulum Baru, (Bandung, PT Remaja Rosdakarya, 2013), hlm. 20. 
disebut dengan kegiatan co-curriculer.Kurikulum tak formal ini terdiri atas kegiatan-kegiatan yang juga direncanakan tetapi tidak berkaitan langsung dengan pelajaran akademis dan kelas tertentu.Kurikulum ini dipandang sebagai pelengkap dari kurikulum formal.7

Bagian yang termasuk dalam co-curriculer yaitu kegiatan-kegiatan yang berada di luar jam pelajaran seperti pertandingan antar kelas, pramuka, serta pembiasaan-pembiasaan yang ada di sekolah yang rutin dilaksanakan siswa setiap harinya yang akan menjadikan memliki karakter yang Islami.

Disinilah sekolah sebagai institusi pendidikan formal bukan hanya sekedar mendidik siswa menjadi cerdas secara intelektual dan terampil dari segi keahlian saja, namun juga pada saat yang bersamaan mendidik siswa yang berkarakter kuat dalam kepribadian yang melahirkan sikap dan tindakan yang serba utama sebagai manusia Indonesia yang Islami.8

Seperti halnya lembaga pendidikan yang melaksanakan co-curriculeryaitu di MTs Negeri I dan MTs Negeri II Wonogiri. Peneliti melakukan penelitian di MTs Negeri I dan MTs Negeri II Wonogiri sebab di sekolahan tersebut menerapkancocurriculerberupa pembiasan-pembiasaan ibadah keagaman yang akan menumbuhkan karakter Islami pada siswa.

Pelaksanaanco-curriculerdi MTs Negeri I Wonogiri berdasarkan wawancara langsung dengan Waka Kurikulum Bapak Hadi Priyono, S.Pd bahwasanya, di MTs Negeri I menerapakan pembiasaan-pembiasaan keagamaan, pembiasaan tersebut yaitu adanya 3S (salam, senyum, sapa) pembiasaan bersalaman antara guru dan siswa yang dilakukan pada pagi hari sebelum masuk ke dalam kelas, berdoa dan tadarus bersama-sama setiap pagi sebelum pelajaran dimulai, pelaksanaan shalat dhuha, shalat dzuhur dan ashar secara berjamaah dan dilanjutkan dengan kultum secara bergilir, shalat jumat yang dilakukan secara berjamaah yang sebelumya membaca Al-Qur'an secara bersamasama, infaq jumat, kegiatan BTQ pada hari senin sampai rabu, adanya Blok $M$ yaitu siswa perempuan yang sedang berhalangan shalat yang diberi kajian tersendiri oleh guru yang bertugas untuk mendapat kajian tentang wanita. Kegiatan praktek manasik haji dan shalat jenazah yang diadakan walaupun hanya setahun sekali. Peringatan hari besar islam seperti idul fitri, idul adha, pesantren kilat bulan ramadhan) serta adanya kegiatan ESQ. Kegiatan-kegiatan lainnya yang terdapat pada ekstrakulikuler seperti ekstrakulikuler seni yaitu seni tari, hadroh, musik vocal dan instrument. Ekstrakulikuler olahraga berupa bulu tangkis, voli, sepak bola, pencak silat, ekatrakulikuler PMR, pramuka, dan PMK.9 Pembiasaan-pembiasaan kedisiplinan dan keagamaan yang ada di MTs Negeri I Wonogiri yang mana siswa 7 S. Nasution, Kurikulum dan Pengajaran, (Jakarta: PT Bumi Aksara, 2006), hlm. 5

8 Haedar Nashir, Pendidikan Karakter Berbasis Agama dan Budaya..., hlm. 6.

9 Wawancara dengan Waka Kurikulum MTs Negeri I Wonogiri, Bapak Hadi Priyono, S.Pd pada hari senin tanggal 4 September 2017. akan menjadi terbiasa disiplin dalam segala hal dan atas kesadaranya sendiri melaksanakan ibadah walaupun itu sunnah seperti shalat dhuha, dan secara langsung pembiasaan ini akan membentuk karakter Islami pada siswa. 10

MTs Negeri II Wonogiri berdasarkan wawancara langsung dengan Pembina Keagamaan Ibu Dra. Sri Supatmi, S.Pd.I dan Waka Kesiswaan Bapak Winardi, S.Pd, beliau mengatakan bahwasanya, pembinaan keagamaan di MTs Negeri II Wonogiri lebih menekankan pada pembiasaan beribadah dan kegiatan agama lainnya yang bertujuan untuk membentuk karakter Islami pada siswa. Bentuk pembiasaan di MTs Negeri II Wonogiri berupa kegiatan Abu Salam yaitu pembiasaan bersalaman anatara guru dengan siswa pada pagi hari di depan gerbang sekolahan sebelum siswa masuk kelas, membaca doa kemudian dilanjutkan dengan tadarus Al-Qur'an sebelum pelajaran dimulai, jumat khusuk berupa kegiatan shalat dhuha dilanjutkan dengan berdzikir berdoa bersama dan kemudian membaca Al-Qura'an secara bersama-sama, pendisiplinan shalat dhuha, shalat dzuhur berjamaah, dan jumat khusuk yang dipantau langsung oleh guru Pembina keagamaan juga diadakan buku persensi bagi siswa perempuan yang sedang berhalangan shalat. Kegiatan lainya yang dituangkan dalam ekstrakulikuler seperti BTQ wajib bagi kelas VII dan siswa yang belum lancar membaca Al-Qur'an, Qiro'ah, kegiatan seni seperti Hadro, Tahfidz yang bagi kelas Program Khusus wajib menghafal juz 30 , peringatan hari besar keagamaan (idul adha, idhul fitri, pesantren pada bulan ramadhan). Di MTs Negeri II Wonogiri juga mempunyai sarana dan prasarana berupa Lap agama yang berfungsi untuk kegiatan praktik pada pelajaran Agama.Pembiasaan ini ditekankan pada siswa untuk memberikan pengaruh positif dalam pembentukkan karakter Islami pada siswa MTs Negeri II Wonogiri.11

Berdasarkan latar belakang diatas tertarik untuk diketahui dan digali lebih dalam mengenai cocurriculer yang diterapkan di sekolah MTs Negeri IWonogiri dan MTs Negeri II Wonogiri.Melalui co-curriculer tersebut penelitian ini berjudul "Implikasico-curriculer dalam Meningkatkan Karakter Islami Siswa Kelas VIII di MTs Negeri IWonogiri dan MTs Negeri II Wonogiri Tahun Pelajaran 2017/2018.

\section{METODE PENELITIAN}

Jenis kegiatan penelitian ini termasuk katagori penelitian lapangan (field Research) yaitu penelitian yang pengumpulan datanya berada di lapangan. Adapun jenis penelitiannya adalah penelitian kualitatif yang bersifat deskriptif, yaitu mendeskripsikan suatu objek, fenomena dalam suatu tulisan yang berbentuk naratif. Laporan penelitian berisi kutipan-kutipan

10 Wawancara dengan Bidang Keagamaan MTs Negeri I Wonogiri, Ibu Dra.Siti Noor Asih pada hari senin tanggal 4 September 2017.

11 Wawancara dengan Dra. Sri Supatmi, S.Pd.I, Pembina Keagamaan dan Waka Kesiswaan Bapak Winardi, S.Pd MTs N II Wonogiri, pada hari Senin 21 Agustus 2017. 
dari data atau fakta yang diungkap di lapangan untuk memberikan ilustrasi yang utuh dan memberikan dukungan terhadap apa yang disajikan.12

Subjek penelitian pada penelitian ini yaitu kepala Sekolah, guru, dan siswa yamg akan memberikan informasi, data, dan keterangan yang terait dengan peneitian ini. Objek pada penelitian ini yaitu di MTs Negeri I dan MTs Negeri II Wonogiri khususnya kelas VIII.

Metode pengumpulan data terdiri dari metode observasi adalah pengamatan terhadap suatu objek secara langsung untuk mengetahui keberadaan objek, situasi, konteks, dan maknanya dalam upaya mengumpulkan data penelitian.13Dalam hal ini, secara langsung terjun ke lokasi penelitian untuk melakukan pengamatan untuk mendapatkan data yang diperlukan. Data yang dikumpulkan lewat observasi adalah berupa kegiatan pembiasaan yang ada di MTs Negeri I dan MTs Negeri II Wonogiri. Peneliti menggunakan metode wawancara dari sumber yang relevan berupa pendapat, kesan, pengalaman, pemikiran untuk mendapatkan informasi secara mendalam. Wawancara tersebut dilakukan kepada kepala sekolah MTs Negeri I dan MTs Negeri II Wonogiri, guru pembina keagamaan, dan juga murid. Murid yang diwawancarai yaitu kelas VIII berjumlah 5 orang dari masing-masing sekolah, yang diwawancarai adalah ketua kelas sebagai perwakilan dari masing-masing murid.Metode Dokumentasiakan diperoleh data tentang gambaran umum dan sejarah berdirinya sekolah dari MTs Negeri IWonogiri dan MTs Negeri II Wonogiri.

Teknik analisis data, setelah data-data terkumpul kemudian dianalisis, analisis data yaitu pengolahan data untuk menarik suatu kesimpulan.Dalam penelitian ini bersifat deskriptif kualitatif. Data-data yang diperoleh dianalisis dalam beberapa tahap yaitu: a). Tabulasi dan klasifikasi data, mengumpulkan data-data yang berkaitan dengan co-curriculer dalam kegiatan sekolah melalui observasi dan wawancara serta dokumen-dokumen sekolah yang terkait.14 b). Reduksi data, tahap ini merangkum, memilih hal-hal yang pokok, memfokuskan hal-hal yang penting, dicari tema dan polanya dan membuang yang tidak perlu. Dengan demikian akan memberikan gambaran yang jelas dan mempermudah peneliti untuk mengumpulkan data. c). Interpredasi data, apabila data yang didapat sudah spesifik tahap selanjutya menginterpretasikan data atau mendiskripsikan hasil penelitian secara sejelas. 15 d). Kesimpulan data, tahap terakhir yaitu menarik kesimpulan dari hasil analisis, sehingga akan mendapatkan kesimpulan akhir tentang gambaran hasil penelitian. Teknik penyimpulan data ini menggunakan metode induktif dengan mencari data sebanyak-banyaknya kemudian disimpulkan menjadi hipotesa kemudian disimpulkan (umum-khusus).16

12 Djam'an Satori, Aan Komariah, Metodologi Penelitian Kualitatif, (Bandung: Alfabeta, 2012), hlm. 28.

13 Ibid, hlm. 105.

14 Ibid, hlm. 236.

15 Sugiyono, Metode Penelitian Pendidikan Pendekatan Kualitatif, Kuantitatif, dan R\&D, (Bandung: Alfabeta, 2016), hlm. 334.

16 Suharsimi Arikunto, Prosedur Penelitian Suatu Pendekatan

\section{HASIL PENELITIAN \& PEMBAHASAN}

\section{Implikasi co-curriculer dalam Menumbuhkan Karakter Islami}

Bahwa co-curriculermempunyai hubungan dengan pembentukkan karakter siswa yaitu cocurriculermerupakan suatu cara dalam pembentukkan karakter. Misalnya adannya kegiatan pembiasaan keagamaan di dalam pelajaran atau diluar jam pelajaran seperti pembiasaan shalat dhuha, shalat berjamaah, membaca Al-Qur'an akan membawa dampak besar terhadap pemahaman keagamaan pada siswa, dari pembiasaanterdapat nilai karakter pada siswa yaitu menjadi Islami, tanggung jawab, dan juga disiplin. Oleh sebab ituco-curriculerdapat membantu pembentukkan karakter Islami pada siswa. Hal ini seperti yang telah dijelaskan di bab II bahwacocurriculersebagai upaya meningkatkan kecerdasan spiritual siswa dengan diadakan ritual keagamaan di luar jam sekolah akan membawa dampak besar terhadap pemahaman kegamaan siswa. oleh sebab itu co-curriculerdapat membatu pencapain tujuan dan pendidikan nasional yang menjadikan siswa bukan hanya cerdas secara intelektual saja tetapi juga cerdas secara spiritual.

Melalui pembiasaan yang dilaksanakan di sekolah siswa akan menjadi terbiasa dalam melaksanakan apa yang telah menjadi kewajibannya seperti shalat. Pembiasaan ini menjadi salah satu metode yang efektif dalam pembentukkan karakter. Seperti yang telah dijelaskan pada bab II bahwa strategi pembentukkan karakter terdiri dari keteladanan guru, penanaman dan penegakakan kedisiplinan yang merupakan pembiasaan bersikap disiplin, menciptakan suasana yang kondusif serta integrasi dan internalisasi. Jika anak dari kecil diajarkan dan dibiasakan untuk mengerjakan kewajiban shalat lima waktu maka kewajiban shalat lima waktu itu sudah terbiasa dilakukannya dan tidak akan meninggalkan kewajiban shalat lima waktu dalam situasi apapun. Agar pembiasaan ini menjadi lebih efektif haruslah didukung dengan adanya keteladanan dari guru, dimana ada pembiasaan disana pasti ada keteladanan.

Penerapanco-curriculer dalam kegiatan pembiasaan di MTs Negeri Idan MTs Negeri II Wonogiri mempunyai dampak yang positif bagi peserta didik.Setiap kegiatan pembiasaan yang berlandaskan agama dan ekstrakulikuler menambah pemahaman dan ketaatan siswa dalam beribadah. Siswa menjadi lebih santun dan berakhlak mulia.

Berdasarkan hasil wawancara dengan salah satu murid kelas VIII MTs Negeri IWonogiri Alif Darma Ihsandi yang telah telah dijelaskan pada bab IIIbahwa dengan adannya kegiatan pembiasaan yang ada di sekolah membuat perubahan pada dirinya yang semula jarang shalat tetapi sekarang shalat lima waktu. Begitu juga wawancara dengan Ibu Dra. Sri Supatmi yang telah dijelaskan pada bab IIIbeliau mengatakan bahwa siswa yang baru masuk ke MTs Negeri II Wonogiri ini masih sulit untuk diajak shalat

Praktek..., hlm. 236. 
bahkan harus disuruh-suruh, sebab di rumah tidak dipantau oleh orang tuanya, kebanyakan dari mereka ditinggal merantau oleh orang tuanya. Tetapi dengan adannya pembiasaan yang terus berulang-uang dan keteladanan dari guru siswa menjadi tahu apa yang telah menjadi kewajibannya sebagai muslim, siswa juga bisa merasakan sendiri manfaat dari melaksanakan shalat tersebut.

Hal tersebut menunjukkan bahwa, sikap perubahan yang terjadi pada siswa merupakan adanyaco-curriculeryang diterapkan di sekolah guna menumbuhkan karakter Islami pada siswa.Cocurriculermerupakan suatu cara untuk menjadikan siswa yang memiliki sikap Islami dan sikap sosial yang baik, walaupun dinyatakan berhasil akan tetapi tidak semua siswa langsung bisa berubah secara keseluruhan menjadi sempurna, tetapi perubahan itu nampak kearah yang lebih baik. Pendidikan karakter bagi siswa sangatlah penting dan harus ditanamkan dan dibiasakan sejak dini.

Begitu juga yang telah dijelaskan pada bab II bahwa untuk menghadapi persoalan nasional dan global diperlukan karakter yang kuat. Jika dalam kehidupan masih terdapat perilaku yang menyimpang maka akar permasalahnya terletak pada karakter manusiannya.Disinilah perlunya benteng akhlak, moral, dan kepribadian atau karakter. Tetapi jika memiliki karakter yang kuat maka tidak akan jatuh dalam hal-hal yang menyimpang.

Setelah penerapan karakter Islami melaluicocurriculerberhasil memberikan dampak yang positif bagi siswa, melalui co-curriculer pencapaian visi, misi juga sekolah dapat tercapai. Selain itu melaluicocurriculermemberikan manfaat besar bagi madrasah yaitu menjadikan nama madrasah semakin unggul di masyarakat, sebab nama madrasah dahulu dipandang sebelah mata oleh masyarakat. Namun setelah diterapkannya program-program sekolah seperti adannya pembiasaan melalui co-curriculer dan adanya Kelas Program Khusus menjadikan madrasah lebih dipandang dan diperhitungkan oleh masyarakat sebab siswannya mempunyai karakter religus.

Terbentuknya karakter Islami pada siswa menjadi ciri khas dari MTs Negeri Idan MTs Negeri II Wonogiri.Sebab mereka mendapatkan lebih banyak pelajaran agama serta pembiasaan beribadah yang lebih banyak dibandingkan dengan sekolah umum. Dengan demikian dengan diterapkannya pembiasaan melalui co-curriculermemberikan pengaruh yang besar baik terhadap siswa maupun sekolah.

\section{Faktor Pendukung}

1) Adannya guru Pembina yang sesuai pada bidangnya yaitu guru Pembina kaeagamaan.

2) Kedekatan antara guru dengan siswa melalui komunikasi kepada siswa menjadi hal yang paling utama dalam pendidikan karakter untuk membentuk nilai-nilai karakter pada siswa. Seperti yang telah dijelaskan pada bab IIIkedekatan antara guru dengan siswa nampak pada kegiatan pembiasaan senyu, salam, sapa
(3S)

3) Faktor pendukung lainnya di MTs Negeri IWonogiri yaitu diadakannya kegiatan ESQ. Kegiatan ini ialah sebuah metode pembangunan jiwa yang menggabungkan antara dua unsur kecerdasan yaitu kecerdasan emosional (EQ) dan kecerdasan spiritual (SQ) dengan memanfaatkan kekutan pikiran bawah sadar atau dikenal dengan sebuta suara hati.

4) Sarana dan prasarana yang lengkap seperti masjid, kelengkapan Ihram untuk manasik haji, kelengkapan mengurusi jenazah, dan lainnya, sehingga memperlancar proses pendidikan karakter. Hal tersebut telah dijelaskan pada bab III.

5) Lingkungan sekolah yang mendukung, seperti suasana sekolah yang nyaman. Suasana yang yang kondusif dan nyaman akan sangat mendukug proses pembelajaran di sekolah. Selin itu juga dengan adannya kegiatan pembiasaan menjadi faktor pendukung terlaksananyacocurriculerdalam pembentukkan karakter siswa.

\section{Faktor Penghambat}

1) Kesadaran siswa yang masih kurang taat beribadah.

2) Perhatian dari orang tua yang kurang membuat penghambat dalam terlaksananya pembentukkan karakter pada siswa.

3) Banyak dari siswa yang ditinggalkan orang tuannya merantau sehingga siswa kurang mendapat pantauan dari orang tuannya.

4) Ketaatan beribadah dari lingkungan tempat tinggal siswa yang masih kurang.

\section{Keunggulan}

\section{MTs Negeri I Wonogiri}

1) Terdapat kegiatan ESQ yang memberikan motivasi kepada siswa

2) Lingkungan belajar yang kondusif, baik lingkungan fisik maupun social psikologis

3) Kegiatan ekstrakurikuler yang mampu menampung semua kemampuan, minat, dan bakat siswa. Keragaman ekstrakurikuler akan membuat siswa dapat mengembangkan berbagai kemampuannya di berbagai bidang secara optimal.

4) Di MTs Negeri I Wonogiri shalat dhuha sudah berjalan dengan sendirinya, siswa yang datang pagi sebelum bel masuk atas kesadarannya sendiri langsung melaksanakan shalat dhuha secara munfarid. 


\section{MTs Negeri II Wonogiri}

1) Diadakannya kegiatan jumat khusuk yang dapat menambah ketaqwaan kepada Allah, kegiatan ini berisi shalat dhuha berjamaah kemudian dilanjutkan dengan zikir, berdoa, dan membaca Al-Qur'an secara bersama-sama

2) Lingkungan sekolah yang mendukung untuk membentuk karakter yang islami

3) Kebersamaan antara guru dengan siswa yang erat

4) Keteladanan dari para guru yang selalu memberikan contoh yang baik terhadap siswanya.

\section{Solusi dalam Mengatasi Faktor Penghambat dalam Pelaksanakan Co- curriculer dalam Menumbuhkan Karakter Islami Siswa}

Faktor penghambat tersebut ada beberapa solusi yang dapat diberikan yaitu:

1) Hendaknya orang tua memantau anaknya dengan lebih sehingga anak mendapatkan bimbingan bukan hanya di sekolah tetapi juga di rumah.

2) Lebih dibangunnya komunikasi antara guru dengan orang tua siswa secara intens untuk memantau perkembangan siswa di sekolah.

3) Hendaknya guru selalu memberikan motivasi kepada siswa agar siswa menjalankan apa yang telah menjadi kewajibannya, dengan harapan motivasi itu menjadi pendorong siswa untuk menjadi manusia yang berkarakter baik.

4) Sekolah mengupayakan terciptanya keselarasan antara karakter yang dikembangkan dengan pembiasaan di rumah dan masyarakat

5) Hendaknya sekolah mengadakan buku kegiatan perkembangan siswa untuk memantau perkembangan siswa yang kemudian akan disampaikan atau diberikan kepada orang tua siswa

\section{PENUTUP}

Implikasi Co-curriculer dalam Menumbuhkan Karakter Islami Siswa Kelas VIII di MTs Negeri Idan MTs Negeri II Wonogiri. Melalui pembiasaan yang dilaksanakan di sekolah siswa akan menjadi terbiasa dalam melaksanakan apa yang telah menjadi kewajibannya seperti shalat. Pembiasaan ini menjadi salah satu metode yang efektif dalam pembentukkan karakter. Penerapan co-curriculer dalam kegiatan pembiasaan di MTs Negeri Idan MTs Negeri II Wonogiri mempunyai dampak yang positif bagi peserta didik.Setiap kegiatan pembiasaan yang berlandaskan agama dan ekstrakulikuler menambah pemahaman dan ketaatan siswa dalam beribadah. Siswa menjadi lebih santun dan berakhlak mulia.Hal tersebut menunjukkan bahwa, sikap perubahan yang terjadi pada siswa merupakan adanya co-curriculer yang diterapkan di sekolah guna menumbuhkan karakter Islami pada siswa.Co-curriculer merupakan suatu cara untuk menjadikan siswa yang memiliki sikap Islami dan sikap sosial yang baik, walaupun dinyatakan berhasil akan tetapi tidak semua siswa langsung bisa berubah secara keseluruhan menjadi sempurna, tetapi perubahan itu nampak kearah yang lebih baik. Pendidikan karakter bagi siswa sangatlah penting dan harus ditanamkan dan dibiasakan sejak dini.

Implikasi Tehadap Sekolah. Setelah penerapan karakter Islami melalui co-curriculerberhasil memberikan dampak yang positif bagi siswa, melalui co-curriculer pencapaian visi, misi juga sekolah dapat tercapai. Selain itu melalui co-curriculermemberikan manfaat besar bagi madrasah yaitu menjadikan nama madrasah semakin unggul di masyarakat, sebab nama madrasah dahulu dipandang sebelah mata oleh masyarakat. Namun setelah diterapkannya programprogram sekolah seperti adannya pembiasaan melaluico-curriculer dan adanya Kelas Program Khusus menjadikan madrasah lebih dipandang dan diperhitungkan oleh masyarakat sebab siswannya mempunyai karakter religus.

Terbentuknya karakter Islami pada siswa menjadi ciri khas dari MTs Negeri Idan MTs Negeri II Wonogiri.Sebab mereka mendapatkan lebih banyak pelajaran agama serta pembiasaan beribadah yang lebih banyak dibandingkan dengan sekolah umum.

Faktor pendukung di antaranya: Adannya guru Pembina yang sesuai pada bidangnya yaitu guru Pembina kaeagamaan. Kedekatan antara guru dengan siswa melalui komunikasi seperti diadakannya kegiatan pembiasaan senyum, salam, sapa (3S) di MTs Negeri IWonogiri, dan Abu salam di MTs Negeri II Wonogiri. Faktor pendukung lainnya di MTs Negeri IWonogiri yaitu diadakannya kegiatan ESQ. Sarana dan prasarana yang lengkap. Lingkungan sekolah yang mendukung, seperti suasana sekolah yang nyaman. Suasana yang yang kondusif dan nyaman akan sangat mendukug proses pembelajaran di sekolah. Selain itu juga dengan adannya kegiatan pembiasaan menjadi faktor pendukung terlaksananya co-curriculerdalam pembentukkan karakter siswa.

Faktor Penghambat. Kesadaran siswa yang masih kurang taat beribadah. Perhatian dari orang tua yang kurang membuat penghambat dalam terlaksananya pembentukkan karakter pada siswa. Banyak dari siswa yang ditinggalkan orang tuannya merantau sehingga siswa kurang mendapat pantauan dari orang tuannya. Ketaatan beribadah dari lingkungan tempat tinggal siswa yang masih kurang. Belum diterapkannya jam wajib belajar di lingkungan tempat tinggal siswa. 


\section{DAFTAR PUSTAKA}

Arikunto, Suharsimi. 2006. Prosedur Penelitian Suatu Pendekatan Praktek. Jakarta: PT Rineka Cipta.

Departemen Agama RI. 2007. al-Qur'an dan Terjemahan. Bandung: PT. Sigma Examedia Arkanleema.

Hamid, Hamdani dan Beni Ahmad Saebeni.2013. Pendidikan Karakter Perspektif Islam. Bandung: Pustaka Setia.

Hidayatullah, M. Furqon. 2010. Pendidikan Karakter: Membangun Peradaban Bangsa. Surakarta: Yuma Pressindo.

Hidayat, Soleh. 2013. Pengembangan Kurikulum Baru. Bandung: PT Remaja Rosdakarya.

Nashir, Haedar. 2013. Pendidikan Karakter Berbasis Agama dan Budaya. Yogyakarta: Multi Presindo.

Nasution, S. 2006. Kurikulum dan Pengajaran. Jakarta: PT Bumi Aksara.

Satori, Djam'an dan Aan Komariah. 2012. Metodologi Penelitian Kualitatif. Bandung: Alfabeta.

Sugiyono. 2016. Metode Penelitian Pendidikan Pendekatan Kualitatif, Kuantitatif, dan R\&D. Bandung: Alfabeta.

Undang- Undang RI No 20 Tahun 2003 tentang Sistem Pendidikan Nasional. 2013. Jakarta: Departemen Pendiidkan Nasional RI. 